\title{
Supporting the victims of family violence: How to help?
}

\section{Wspieranie ofiar przemocy domowej - jak pomagać?}

\author{
Monika I. DąbkowskaA-F \\ Department of Tanatopedagogy and Therapy, Faculty of Education, Nicolaus Copernicus University in Torun, Poland \\ A - research concept and design; $\mathrm{B}$ - collection and/or assembly of data; $\mathrm{C}$ - data analysis and interpretation; \\ $D$ - writing the article; $E$ - critical revision of the article; $F$ - final approval of article
}

Address for correspondence

Monika I. Dąbkowska

E-mail:mdabkow@umk.pl

Conflict of interests

None declared

Received on April 20, 2017

Revised on June 5, 2017

Accepted on August 29, 2017

\begin{abstract}
Violence is an interdisciplinary problem that involves numerous professionals, mainly from the fields of law, health science and social sciences. It is important to know the characteristics of violence and the scale of this phenomenon. In recent years, there have been many publications dealing with the consequences of experiencing violence. The purpose of this article is to elucidate the issue of domestic violence, its consequences and possible forms of assistance for its victims. The consequences of experiencing violence during both childhood and adulthood are discussed. The legal regulations concerning persons exposed to domestic violence in Poland are presented. The latest statistics on victims of domestic violence are also cited. The forms of psychotherapy are discussed. The role of systemic, individual and group therapy in the help process is highlighted; supportive factors are discussed. Helping victims of domestic violence requires the cooperation of professionals from a wide range of fields, dealing with broadly defined mental and public health. It is also crucial - from the perspective of building and strengthening social as well as health support networks - to constantly discuss this subject in pedagogical, psychological and medical literature.
\end{abstract}

Key words: family, psychotherapy, violence 


\section{Streszczenie}

Przemoc jest problemem interdyscyplinarnym, którego rozwiązanie wymaga udziału wielu specjalistów, głównie z dziedziny nauk prawnych, nauk społecznych i nauk o zdrowiu. Ważne jest, aby znać cechy przemocy i skalę zjawiska. Wiele publikacji z ostatnich lat dotyczy konsekwencji przemocy. Celem tego artykułu jest przybliżenie kwestii przemocy, jej skutków i możliwych form udzielania pomocy ofiarom. Omówione zostały konsekwencje przemocy doświadczanej zarówno w dzieciństwie, jak i dorosłości. Zaprezentowano przepisy polskiego prawa dotyczące osób narażonych na przemoc w rodzinie. Przytoczono także najnowsze statystyki dotyczące ofiar znęcania się nad rodziną. Omówiono formy psychoterapii. Podkreślono rolę terapii systemowej, indywidualnej oraz grupowej, w procesie pomocy, a także czynniki pomagające. Poza współpracą profesjonalistów zajmujących się zdrowiem psychicznym i publicznym istotne jest też - z perspektywy budowania i wzmacniania sieci wsparcia społecznego, ale i zdrowotnego - nieustanne poruszanie omawianej tematyki w literaturze pedagogicznej, psychologicznej i medycznej.

Słowa kluczowe: rodzina, psychoterapia, przemoc

\section{Introduction}

Violence is an interdisciplinary problem that concerns numerous professionals, mainly from the fields of law, health science and the social sciences. In recent years, there have been many publications dealing with this issue and describing possible actions, which may effectively reduce this phenomenon. The purpose of this article is to elucidate the issue of violence, its consequences and possible forms of assistance for its victims.

\section{The characteristics of violence and the scale of the phenomenon}

The World Health Organization (WHO) defines violence as the intentional use of physical force or power, threatened or actual, against oneself, another person, or against a group or community, which either results in or has a high likelihood of resulting in injury, death, psychological harm, maldevelopment or deprivation. ${ }^{1}$

Violence is a multifaceted phenomenon - families nowadays go through quick and varied transformations that resonate with the socio-political and economic changes in society. ${ }^{2}$ These changes often contribute to the disorganization of life within the family. Violence is, unfortunately, also acting against a family member detrimental to his/her rights and violating his/her individuality, dignity and position in society. These actions most frequently affect women, children and the elderly. Violent behavior is deliberate, intentional actions that go beyond social norms. It results from an imbalance of power or authority - with the advantage to the aggressor over the victim. The purpose of such behavior is imposing power, inflicting harm to another person, violation of personal goods and rights and interference in other people's freedom. This may turn a victim torpid in some way. ${ }^{3}$

In the literature we find descriptions of various forms of violence. The most common are: physical violence, psychological violence, sexual violence, economic violence and neglect. ${ }^{4}$ Physical abuse involves undertaking be- haviors aiming to hurt the victim. Such behaviors, occur against the victim's will, may lead to personal injury, damage to health or - in the end - to the deprivation of life. The perpetrators of psychological violence aim to reduce the self-esteem of the victim, inducing fear through humiliation, threatening, embarrassment, or limiting contact with loved ones. Sexual abuse involves forcing the victim into undesired sexual intercourse, making remarks of a sexual nature and/or taking up behavior to damage the genitals. Economic violence is manifested by excessive control of spendingmoney, taking it away by force, issuing bans on going to work, destroying personal belongings, taking loans against the will of the partner, and stealing. Neglect is not meeting the basic physical and emotional needs of the victim; such behaviors may be conscious or unconscious, and may result from the incompetence and lack of interest of the perpetrator. ${ }^{5}$

Domestic violence is not a single act. Mental and physical bullying, humiliation, fights, screaming, or beating the partner or the children is reality for many families. It is rarely said, but it does not apply only to so-called "pathological families". It also concerns those who, in the public eye, may be considered well-functioning. Violence can occur in any social group, regardless of the level of education, or financial status. Among the factors that generate violence in the family, there are: the experience of violence in childhood, social stress, addiction and/or illness, the negative consequences of rapid urbanization and industrialization, and social isolation of the family. ${ }^{6}$

In Poland, the number of victims and perpetrators of violence has been increasing year by year, which is reflected in police statistics that take into account the phenomenon of domestic violence with the use of the Poland Domestic Abuse Helpsystem, which is named "blue card". It might also be due to social changes and more frequent reporting, as well as the development of education and awareness of rights. In 2016, there were 91,789 victims of violence recorded (including 66,930 women, 14,223 children and 10,636 men). In the same year, 59,590 victims filled out forms of the "blue card". 


\section{The consequences of experiencing violence}

In the literature, descriptions of the impact of violence on the physical functioning and mental health of the victim. The conclusions that come from many studies indicate that violence is associated with the occurrence of the victim's mental discomfort. These studies reveal that individuals who have suffered from experiencing violence are much more likely to rate their health as poor. Also they are more at risk of developing post-traumatic stress disorder (PTSD) symptoms, headaches, depression, eating disorders, problems of a sexual nature, suicide, psychosis schizophrenic syndrome, chronic pain and substance abuse. Violence also fosters the onset of symptoms of social anxiety. Experiencing abuse in childhood can contribute to the onset of depression among preschool and school children. Long-term consequences can also include ischemic heart disease and irritable bowel syndrome. The cause-and-effect relationships between harming the family, explicit health and developmental problems are obvious and proven. 8,9

The consequences of experiencing violence by children are particularly described. It is believed that experiencing physical, verbal or sexual abuse in young age, witnessing parental domestic violence, experiencing parental divorce, and living with someone who was depressed, addicted drugs or alcohol, or who had been incarcerated, were associated with 1 or more of the following health outcomes: low self-rated health, functional limitations, diabetes and heart attack. Adult socioeconomic status and poor mental health and health behaviors significantly mediated several of these associations. ${ }^{10}$ Maltreatment suffered during childhood has long-term consequences, which risk impacting on parenthood. Supporting victims of violence in childhood as they adapt to parenthood represents a challenge for professionals working in perinatal services.

\section{The signs of violence}

Skillful recognition of the distressing symptoms of violence makes it possible to perform rapid diagnosis and undertake effective multi-faceted actions. The signs of physical abuse, which include somatic symptoms such as bruises, bloody petechiae, lacerations, open wounds, fractures, swelling, alopecia and burns, are the most visible. The size of these lesions is often inadequate for the causes as described by the person. Wearing clothes that cover limbs and reluctance to expose selected parts of the body are also characteristic. ${ }^{11}$

The signs of psychological abuse include: anxiety, sadness, withdrawal or not reacting to attempts to make contact, low self-esteem, aggression, excessive submission or attempts of suicide. Speech disorders and nocturnal enuresis may also occur among children. ${ }^{12}$

Sexual violence often ressults in bruising around the genitals, unexplained occurrence of venereal diseases, urinary tract infections and vaginal pains in the groin, back pain, depression, eating disorders, sleep disorders, behavioral changes, failure at school or at work, abuse of psychoactive substances or pregnancy. ${ }^{13}$

Neglect leads to inadequate nutrition of the victim, untreated diseases, dehydration, neglect of personal hygiene (especially when it concerns children and the elderly), the feeling of loneliness or lack of basic quality of life at home despite appropriate conditions. ${ }^{14}$

It may be noted that these symptoms of violence - particularly among children - are uncharacteristic. However, emerging abnormal behavior in contact with peers, adults or parents may suggest a disservice and should motivate them to observe the person carefully and take consistent action. Early detection of child abuse requires a systematic and careful diagnostic approach. ${ }^{15}$

\section{Legal regulations concerning forms of assistance for victims of violence}

In 2010 in Poland, there was an amendment to the Act on the Prevention of Domestic Violence. ${ }^{16}$ It is the highest legal act, which, together with implementing regulations, indicates the procedure to be followed in situations of violence. Domestic violence is a crime, understood to be a single or repeated willful act or omission that violates the rights or personal goods of people cohabiting or maintaining a house, particularly exposing these people to the danger of loss of life or health, affecting dignity, physical integrity, freedom (including sexual freedom), causing damage to physical or mental health, or causing suffering and moral damage to those affected. According to the record, one of the main objectives designed to support the families affected by violence is the interdisciplinary involvement of entities from different levels (i.e. departments, institutions, individuals) in diagnosing, intervention and prevention. The law is a common part of the legislation defining the goals and tasks of all the entities involved in the prevention and remedial action. Therefore, it relates to the police and social and health education workers to a similar extent.

However, pursuant to the provisions of the Criminal Code, mistreatment of family members is prosecuted by indictment, and there is no significance whether it concerns an adult or a child. This law on the prevention of domestic violence introduces an immediate obligation by people who are performing professional duties to report suspected domestic violence. ${ }^{17}$ 
In 2011, a rule was established by the Council of Ministers on the procedure of the "blue card". It is a basic instrument of intervention in a family where violence occurs, by duly authorized representatives. ${ }^{18}$

The victims of abuse are often subjected to a long-term process of manipulation, psychological pressure, aggression, harassment, humiliation, isolation, scaring, abuse and addiction by their persecutors. It takes place for years, and those experiencing violence become helpless and vulnerable. They are unable to cope independently. Effective help aims at rebuilding what has sometimes been completely destroyed - confidence, healthy assessment of the situation, decision making skills and the ability to defend one's own rights as well ashealth and life.

\section{Forms of psychotherapy}

It is indicated in the literature that systemic family therapy, individual and group psychotherapy are effective in the healing process of the victims of violence. Family therapy consists of the following stages: establishing contact with the family, describing the family problem, agreeing to the terms of family therapy, continuing therapy, accompanying the family in finding new solutions, terminating the therapy.

The main objective of individual psychotherapy is for the patient to regain control. The therapist supports the autonomy of the victim, and his attention is focused on listening to the victim's statements and allowing him/her to return to the traumatic events that are connected to the rebound. In the case of treatment of victims of violence, group psychotherapy is based on joint work with people with similar, traumatic experiences. They form support groups, and participation in them gives a person experiencing violence a sense of security and support, reducing the sense of isolation and allowing him/her to rebuild relationships with others. Primary healing factors are: sharing each other's experiences, mutual support and celebrating each other's successes. ${ }^{19,20}$

In the treatment process, people who are the victims of violence require a lot of patience and determination as well as a deep understanding of their situation. The therapist often has a difficult task to convince the victims to take action in order to break the pattern of violence, which always requires time and commitment.

It is also important that specialists from various fields take part in the treatment. The therapy of people who have experienced violence should take into account the biological, psychological and social consequences of traumatic events. The victims of violence do not only need psychological support - they also require physical protection, often financial support along with social and legal advice. Psychoeducation and psychotherapy support is advisable at the beginning of the treatment. The thera- peutic relationship should be based on mutual cooperation, strengthening the sense of control and influence, which gives the victim a sense of security. The condition essential for the effective search of appropriate methods and therapeutic techniques tailored to the needs of the patient is a flexible, open attitude of the therapist. An individualized therapeutic approach helps the victim to rebuild identity.

An essential point in the therapy process is the principle of normalization. This is an assumption that all the feelings experienced by the victim of violence are a normal reaction to an abnormal situation. When restoring dignity, victims of violence find meaning in: the facts provided by the therapist explaining the ailment, receiving information about returning to balance, and signs of pathology. It is equally important to focus on the patient's resources, which support the process of coping - social support, a sense of humor, optimism and the ability to make sense of traumatic events.

Good acceptance, as well as the effects on symptomatology and other relevant therapeutic variables, provides a first indication of successful treatment of victims of violence in a clinical context. ${ }^{21}$ To sum up, the perception of harm is undoubtedly an ethical act. In this case, specialists are required to be inquisitive, reliable and mindful. Early identification and reporting to the relevant organizations helps in resolving problems, and leads the patient to the necessary health care. The key task is prophylactic measures aimed at preventing intentional and unintentional physical and mental injuries among children and adults. $^{22}$

\section{Conclusions}

An analysis of information gathered by a specialist about a person experiencing violence and his or her family makes it possible to distinguish the most important areas in which assistance is needed. Considering a broad context enables the planning of interdisciplinary cooperation, which is most often indispensable in the case of people affected by violence. Direct therapeutic work is not always effective; we need an analysis of the environmental factors affecting human functioning, which may empower us to learn the causes of this ineffectiveness, and enable us to form new therapeutic goals, which take the whole context of human life into account. Experience in diagnostic and therapeutic work, as well as an analysis of the literature on selected issues, make it possible to find the right way to help people experiencing violence: - The therapy and help of those those affected should cover many aspects of their lives, and rely on interaction with the wider environment. Such actions are more effective and more durable.

- The therapy should be adapted to the current developmental period of a person. It must be based on the ac- 
tual competences of the person, and the consequences of experiencing violence and disclosing the violence during that development must also be taken into account. - Helping the harmed should take into account the characteristics of the environment in which the person lives - the way the family and the closest social circles function.

Regardless of the type of violence experienced and the consequences revealed in the development of the individual, it will always be crucial to combine the specific knowledge about violence and a functioning analysis of the individuals from a developmental perspective. These enable a comprehensive diagnosis and make it possible to create effective help programs that concern the broadlydefined environment. In the process of helping people who have been affected by violence, supportive and decentralizing cooperation with other professionals is particularly important.

\section{References}

1. Definition and typology of violence. Violence Prevention Alliance Web site. http://www.who.int/violenceprevention/approach/definition/en. Accessed June 2017.

2. Duda M. Violence in the family as challenge for modern social work. Studia Socialia Cracoviensia. 2012;4(1):99-112.

3. Stodulska-Blaszke A, Wójcicka A. Domestic violence: The situation of the victim. Curr Probl Psychiatry. 2010;11(2):142-144.

4. Ciesielska M. Rodzaje, formy i cykl przemocy w rodzinie. Zeszyty Naukowe Państwowej Wyższej Szkoły Zawodowej im. Witelona w Legnicy. 2014;12:9-13.

5. Makara-Studzińska M, Madej A. Ofiary przemocy - jak pomagać, jak rozmawiać. Psychiatr Dypl. 2015;5:39-44.

6. Sirois M, Berthelot N, Drouin-Maziade C, et al. Child abuse and parenting. Soins Pediatr Pueric. 2015;284:44-47.

7. Police Headquarters. Web site. http://statystyka.policja.pl. Accessed March 2017.

8. Wilson $\mathrm{D}$, Kliewer W, Sica D. The relationship between exposure to violence and blood pressure mechanisms. Curr Hypertens Rep. 2004;6(4):321-326.

9. Wright E, Fagan A, Pinchevsky G. The effects of exposure and victimization across life domains and substance use. Child Abuse Negl. 2013;37(11):899-909.

10. Monnat S, Chandler R. Long term physical health consequenses of adverse childhood experiences. Sociol Q. 2015;56(4):723-752.

11. Stringham P. Domestic violence. Prim care. 1999;26(2):373-384.

12. Zimmerman G, Posick C. Risk factors and behavioral consequences of direct versus indirect exposure to violence. Am J Public Health. 2016;106(1):178-188

13. Schwartz I. Sexual violence against women: Prevalence, consequences, societal factors, and prevention. Am J Prev Med. 1991;7(6):363-373.

14. Biskupska M. Przeciwdziałanie przemocy w rodzinie - rola profesjonalistów podstawowej opieki zdrowotnej. Now Lek. 2013;82(3): 246-252.

15. Otterman G, Tindberg $Y$. Injuries from violence in young childrensigns, management and diagnostics. Lakartidningen. 2014;111(47):2098-2101.

16. Act of 10 June 2010 amending the Law on the prevention of domestic violence and certain other acts. Journal of Laws of 2010 No. 125 , item 842.

17. Obiegło A. Sprawcy przemocy $w$ rodzinie: Przegląd środków karnych i instrumentów oddziaływania przewidzianych w polskim prawie oraz ich zastosowanie. Przeglad Zachodniopomorski. 2011;3:139-163.

18. Sarankiewicz-Konopka B. Niebieska Karta niesie pomoc. Magazyn Lekarski. 2012;1:5.

19. Badura-Madej W, Dobrzyńska-Mesterhazy A. Przemoc w rodzinie: Interwencja kryzysowa i psychoterapia. Kraków: Wydawnictwo Uniwersytetu Jagiellońskiego; 2000.

20. Namysłowska I. Terapia rodzin. Warszawa: Instytut Psychiatrii i Neurologii; 1997.

21. Habel U, Wagels L, Ellendt S, et al. Violence and health: Symptoms, consequences and treatment of victimized patients. Bundesgesundheitsblatt, Gesundheitsforschung, Gesundheitsschutz. 2015;59(1):17-27.

22. Grass H, Gahr B, Ritz-Timme S. Dealing with victims of domestic violence: Suggestion for daily practice. Bundesgesundheitsblatt, Gesundheitsforschung, Gesundheitsschutz. 2015;59(1):81-87. 